\title{
EDUKASIA
}

JURNAL PENELITIAN PENDIDIKAN ISLAM

http:// journal.stainkudus.ac.id/ index.php/ Edukasia

P-ISSN : 1907-7254; E-ISSN : 2502-3039

Vol. 16 N 0.2 T ahun $2021 \mid 267-274$

DOI: 10.21043/edukasia.v16i2.11662

\section{The Effectiveness of Lectures in the Emergency Period for the Spread of C ovid-19}

\author{
Ahmad $\mathrm{H}$ anany $\mathrm{N}$ aseh \\ Universitas I slam N egeri Sunan Kalijaga, Yogyakarta, Indonesia \\ ahmad.naseh@uin-suka.ac.id
}

\begin{abstract}
The pandemic problem facing the world brings change into a new era. Everything is being done to break the chain of transmission of COVID-19. One of them is in the world of education, online learning methods have changed. The purpose of this article is to understand the effectiveness of online lectures in the emergency period of the COVID-19 outbreak. This research is a library research, specifically focusing on journals and books related to the research theme. The results showed that there were students who agreed with the online learning method, but there were students who did not agree. It has been found that the main problems of online lectures are lack of technical mastery, unstable network, higher costs, and the emergence of psychological problems in students.
\end{abstract}

Keywords: Effectiveness, Lectures, Students

\begin{abstract}
Abstrak
M asalah pandemi yang dihadapi dunia membawa perubahan ke era baru. segala hal diupayakan untuk memutus rantai transmisi covid-19. Salah satunya adalah dalam dunia pendidikan, metode pembelajaran online telah mengalami perubahan. Tujuan dari artikel ini adalah memahami efektivitas kuliah daring di masa darurat penyebaran covid-19. Penelitian ini merupakan penelitian pustaka, khususnya fokus pada jurnal dan buku yang terkait dengan tema penelitian. Hasil penelitian menunjukkan bahwa terdapat mahasiswa yang setuju dengan metode pembelajaran online, akan tetapi terdapat mahasiswa yang tidak setuju. Telah ditemukan bahwa permasalahan utama perkuliahan online adalah kurangnya penguasaan teknis, jaringan yang tidak stabil, biaya yang lebih tinggi, dan munculnya masalah psikologis pada mahasiswa.
\end{abstract}

Kata kunci: Efektivitas, Perkuliahan, M ahasiswa 


\section{A. Introduction}

The CO VID-19 pandemic, which is currently occurring in various parts of the world, including Indonesia, has changed the order in all fields, including education. All learning from kindergarten to higher education is affected by the current pandemic. For example, in the education process, the teaching and learning process is usually done face-to-face, now we have to change the distance learning system (PJJ). The process is done online at home using internet technology. Of course, there are many challenges and weaknesses in the implementation process (Purnama, 2020).

All activities in various sectors are disrupted. Everything is being done to break the chain of transmission of the coronavirus disease. Physical distancing is a way to stop the spread of COVID-19. Of course, this has an impact on the field of education which has experienced changes in learning methods. As an effort to prevent the spread of this deadly virus, the government has implemented online learning rules. Therefore, all students can carry out the learning process without meeting face to face.

The use of the best technology is needed to make the learning process effective during this pandemic period. Currently, there are various media that are used as a place for online learning classes or what is commonly called microblogging platforms such as Google Classroom, Learning H ouse, Edmodo, Teacher Room, Zenius, Google Suite for Education, M icrosoft O ffice 365 for Education, your school, Smart Classroom and so on ( D aheri, et al., 2020).

Students and lecturers must be able to adapt to this new learning method. Of course, not everyone can adapt to this. In fact, there are students who are still confused about using technology in the learning process. There are even some lecturers who have difficulty using this new method in delivering material. The intensity of interaction between lecturers and students looks lower than usual. It is also difficult for lecturers to see the level of student understanding in the learning process. Coupled with network restrictions and internet packages that cost more than usual, online lectures are becoming increasingly difficult, but must be done.

In addition, in this pandemic social relations must be carried out indirectly. It can be seen that the interaction between students and other students as well as with lecturers has not been maximized because it is limited to virtual relationships and cannot interact in maximum life because it is limited to virtual relationships and cannot interact in real life. Even Aridarmaputri, Akbar, and Yunairrahmah argue that social interaction is a dynamic social 
relationship between individuals and other individuals, individuals with groups, or groups with other groups that humans need. U nfortunately, these requirements cannot be met normally as usual. In fact, the social value in real life is more easier to obtain than in relationships built through digital technology. Like learning activities that many students complain about, this is due to the many problems in online classrooms that hinder the development of learning activities. However, there is no other choice but online learning, because this situation does not allow normal learning, namely offline learning or face-to-face learning (Aridarmaputri \& Yuniarrahmah, 2016).

\section{B. Discussion}

This article is the result of library research. This type of library research relies almost entirely on research from the literature ( both digital and physical). This research is often called qualitative descriptive literature research or bibliographic research, and can also be called nonreactive research because it fully relies on theoretical data and library materials (M ukhtar, 2013). Researchers obtained data from various books, journals, scientific works, and other documents containing the effectiveness of learning in the emergency period of the spread of COVID-19.

According to law number 20 of 2003 learning is a process of interaction between students and educators with learning resources in the learning environment. Learning is done in order to gain knowledge. Learning activities are common, especially for students, which is an obligation that must be fulfilled. However, recently the learning method used is different from the previous one (Pohan 2020). The COVID-19 pandemic has changed many aspects of human life in this era, so it is called the new normal. Everything is new, meaning that the system or habits that exist in society have changed a lot due to demands from the government to implement many new rules to stop the spread of COVID-19. Some of the rules that must be obeyed by the community are wearing masks, using hand sanitizers, washing hands, staying away from crowds, and doing social distancing .

Rules social distancing and staying away from crowds clearly makes the education sector have to change face-to-face classes into indirect face-to-face classes. This is done by utilizing technology for the interaction process between teachers and students. This learning activity is called online learning. O nline learning is a formal education organized by an educational institution with the aim of connecting students with their instructors and various resources related to learning activities even though they are separated by distance but can interact using an interactive telecommunication system. 
With the availability of many containers or media in online learning, this activity becomes easy to do. H owever, the problem lies in the subjects or people who take advantage of these technological developments. The main problems of online learning are found in the lack of mastery of technology, unstable networks, higher costs, and the emergence of psychological problems such as stress. Within the scope of lectures, all students al ready have supporting tools that can be said to be mandatory, such as smartphones and laptops or notebooks.

The availability of many platforms or online learning media makes learning activities easy to do. The development of the internet is always updated and has many users ( $M$ unir, 2017). H owever, the problem lies in the subject or person using the developing technology. The main problems of online learning are lack of technical mastery, unstable network, high costs, and the emergence of psychological problems such as stress. Within the scope of teaching, all students have mandatory supporting tools such as smartphones and laptops

H owever, there are many students, especially those who are just entering the world of lectures still unfamiliar with its use. M eanwhile, in the current situation, there is no other way but to conduct lectures online. So like it or not, students must be able to adapt to the use of technology in learning activities if they want to follow and continue their education. N ot only students, it turns out that there are lecturers who find it difficult with this new learning method, especially senior lecturers. When the lectures took place, he seemed confused about using existing online learning media and asked for help from other people who were more technologically savyy.

This clearly makes teaching activities ineffective. $N$ ot to mention the unstable network interference. This is commonly experienced by students who live far from the city or live in remote places where it is difficult to find a good internet connection. When the lectures started, it seemed that the intention to learn had been gathered, but in the end the mood dropped due to the unsupportive network. Finally, students become lazy and no longer eager to pay attention to the lecturer's explanation because they have missed the material. N ot only students who can experience network problems, in fact, lecturers can also find who have poor internet connections which make the delivery of material unclear and make students not understand. Plus time becomes inefficient and wasted waiting for a stable connection.

Another important issue is related to finances. N ot all students have wifi access in their respective homes. In fact, many students complain about spending a lot of money in buying internet packages to take online lectures. This is a burden for students, especially the less fortunate. The provision of internet quota subsidies that never came forced them to spend more money to buy internet packages. Finally, students are easily stressed. The parties 
concerned with the provision of internet quota subsidies should be able to distribute them as quickly as possible to all students, especially the less fortunate so that the problem of overspending can be resolved.

Another problem is the number of assignments given by the lecturers, but they do not understand what is being learned and how to complete the task. As a result, students will feel stressed and pessimistic. It takes self-confidence that is embedded in students. Self-confidence is a form of belief in the ability possessed to demonstrate behavior in achieving a goal. Students' self-confidence or belief about their ability to complete assignments is low. The feeling of stress has a negative variable relationship. That is, the higher the student's self-confidence, the lower the stress level. Conversely, the lower the self-confidence, the higher the stress level (Saputri, et al., 2020).

U sually social relationships such as interaction, talking, sharing about problems that are thought of, and joking with friends can reduce student stress. H owever, they cannot do so during a pandemic. It is not possible for them to meet face to face. Actually they can interact using the development of communication technology. H owever, it still doesn't feel the same as meeting in the real world. Existing interactions are limited to long-distance communication carried out in cyberspace.

However, there are also students who experience various kinds of difficulties in participating in online lectures but they do not complain. According to experts, humans are born in a tabularasa frame and then develop in a social environment that determines and shapes their identity, in this case a thickening mindset or mindset, gathering important information ( $A$ bbas \& Erlyani, 2020). If someone is born into a complaining family, it means that the person is surrounded by an unfavorable environment, then the person is likely to become a complainer. But it can also be the other way around, namely someone who grew up in a family who always tries and never gives up even though there are problems, it is very likely that that person will become a person who doesn't complain easily and continues to be enthusiastic. So back to the students themselves. How a person's attitude to the problem will determine the final result. Therefore, it is important to shape one's character to become more qualified and never give up in facing problems, including adaptation to online lecture activities in the midst of the COVID-19 pandemic.

The effectiveness of online lectures can be seen from another perspective. That is, there are some students who do not feel burdened by this new method. They feel that online lectures are much more fun than offline lectures because they don't have to waste energy to go to campus. Especially for students whose original residence is far from the campus location. 
They can stay at home and gather with their families. So they can be close to their parents but education continues. H owever, this is only felt by students where wifi access is available or has sufficient finances to buy internet packages and where the network quality is good. If the network where they live is not supportive, they can be sure they will have trouble too.

Those who are good at technology also have the ability to adapt. O nline learning does not seem to be a serious problem because they are used to using technology. In addition, students who observe the lecturer's explanation from beginning to end will be able to capture a lot of knowledge. The most important skills in learning today are concentrating on introducing the given material, asking some questions that students don't understand, and repeating the learning material in their spare time. 0 ne of the advantages of online lectures is that learning activities can be suppressed so that the lecturer's explanation can be repeated at a later time.

In online learning, especially during the covid-19 pandemic, it is important to manage yourself so you don't feel pressured. Students can change negative thoughts into positive ones, they can control their emotions, make them calmer and reduce stress. Students must be able to see opportunities in every activity, not allowing pessimism and negative thoughts to grow. Always try to believe in your own strength. When you encounter difficulties, don't give up and want to quit. If you make a mistake at the start, don't let yourself down and don't try again. As a student, you have to adapt from stage to stage ( H elmiyyah, et al., 2020).

In addition, gratitude must be instilled in students. G ratitude is an expression of feeling for all the happiness that is experienced. Students should be grateful to be able to continue their studies in the midst of the ongoing pandemic (H elmiyyah, et al., 2020). Fortunately, it is possible to find solutions that can be studied without worrying about the increasing popularity of COVID-19. There must be ease in every difficulty. Controlling positive thoughts, and continuing to be grateful is the key.

Attitudes that must be possessed by students are critical, responsible, mature, independent, have superior achievements and are able to carry out their responsibilities professionally, where the purpose of giving these tasks is to measure students' abilities in the academic field. The learning motivation that exists in students must be increased ( $M$ ayangsari, 2016). Although lectures are conducted online, it is hoped that it will not reduce the enthusiasm of students in studying. Achievement motivation is an important part that drives individuals to achieve success. It can be seen that motivation is a force that drives a person to do something, both internally called intrinsic motivation, as well as encouragement resulting from either positive or negative possibilities that come from outside the individual called extrinsic motivation. The great will of the individual can affect the existing motivation. In 
addition, a child's achievement motivation is the family environment, especially the role of parents who have an intense relationship with children so that they make a major contribution to child development (Afnan, et al., 2020).

\section{Conclusion}

The emergency period for the spread of COVID -19 that hit the world requires that every individual survive must adapt to this new era. In terms of education, learning is carried out online so that learning activities can still be carried out even at long distances. Students have different opinions about the effectiveness of current learning methods. Some individuals find it difficult to adapt to online lectures, while others are not opposed to this new method.

The main problems of online lectures are found in the lack of mastery of technology, unstable networks, higher costs, and the emergence of psychological problems such as prolonged stress. It is important to instill a sense of enthusiasm, confidence, self-motivation and an unyielding attitude in students in dealing with problems. Learning to adapt in the use of technology and trying to understand the material presented by the lecturer is the task of students. For unstable network problems, students can view re-recording of lecture activities when the network has started to improve. The problem of the large number of internet package spending in online lectures can be overcome if students receive internet quota subsidies from the parties concerned in that field.

Education must continue during the COVID-19 pandemic because technology can be used as a learning tool. It's a shame if we don't use the existing availability. The effectiveness of online lectures will be more optimal if the main problems can be overcome. It can be understood that online lectures are the right policy to be carried out during a pandemic, lecturers and students are prohibited from delivering face-to-face lectures for fear that it will increase the transmission of coronavirus disease ( covid-19).

\section{DAFTAR PUST AKA}

A.E. Pohan, 2020. Konsep Pembelajaran Daring Berbasis Pendekatan I/miah. Bandung: Penerbit CV. Sarnu Untung.

A. Afnan, R. Fauzia, \& M. U. Tanau. 2020. Hubungan Efikasi Diri Dengan Stress Pada M ahasiswa Yang Berada Dalam Fase Q uarter L ife Crisis. Jurnal Kognisia.

E.W. Abbas, \& N. Erlyani. 2020. Menulis di Kala Badai Covid-19: Memanage Trauma 
Psikologis M enghindari Psikosomatis. Bandung: Remaja Rosdakarya.

G. S. A ridarmaputri, S. N . Akbar, \& E. Yuniarrahmah. 2016. Pengaruh Jejaring Sosial Terhadap Kebutuhan Afiliasi Remaja. Jurnal Ecopsy.

L. K. Saputri, D. R. L estari, \& R. V. Zwagery. 2020. H ubungan Pola A suh Orang Tua dengan Kepercayaan Diri Remaja di SMK Borneo Lestari Banjarbaru. Jurnal Keperawatan dan Kesehatan.

M. D aheri, J. Juliana, D. Deriwanto, \& A.D. Amda, 2020. Efektifitas Whatsapp Sebagai M edia Belajar Daring. Jurnal Basicedu.

M. D. M ayangsari, 2016. Motivasi Berprestasi M ahasiswa Ditinjau dari Penerimaan O rangtua. Jurnal Ecopsy.

M ukhtar. 2013. M etode Praktis Penelitian D eskriptif K ualitatif. Jakarta: R eferensi.

Munir, 2017. Pembelajaran Jarak Jauh Berbasis Teknologi Informasi dan Komunikasi, Bandung: Alfabeta.

S. Helmiyyah, N. Erlyani, \& M. D. Mayangsari, 2020. Hubungan Rasa Syukur Dengan Altruisme Pada Masyarakat Yang Tinggal Di Wilayah Tambang Batubara Asam-Asam. Jurnal Kognisia. 